() О. І. Хмілярчук, К.т.н., доцент, КПІ ім. Ігоря Сікорського, Київ, Україна

\title{
ОЦІНКА ПОКРИВНОЇ ЗДАТНОСТІ ВІДБИТКІВ, ОТРИМАНИХ ТИСНЕННЯМ ФОЛЬГОЮ НА ТКАНИНАХ
}

\section{У статті представлено результати досліджень щодо оцінки якості тиснення фольгою на тканинах, а саме покривної здатності відбитків. Надано рекомендації щодо опти- мальних режимів технологічного процесу для тиснення на різних за властивостями тканинах.}

Ключові слова: покривна здатність відбитків; металізована фольга; перенесення фольги на тканину; параметри технологічного процесу тиснення; гаряче тиснення фольгою.

\section{Постановка проблеми}

На сьогодні спектр поліграфічних послуг декорування тканин дуже широкий $[1,2]$. Залежно від технології можна перенести повноколірне, півтонове зображення чи однотонну плівку для створення ілюстрації [3, 4]. Декорування тканини фольгою це нова актуальна технологія, що з часом займе своє місце на ринку. Зараз вона використовується під час виготовлення роздрібних одиниць одягу та подарункових паковань з тканини.

\section{Мета роботи}

Встановлення оптимального складу тканин, їх характеристик та технологічного процесу отримання якісного відбитка з максимальною покривною здатністю.

\section{Результати проведених досліджень}

Під час проведення експериментів розглянуто дві технології створення відбитка: традиційне гаряче тиснення фольгою (1) та за допомогою термопресу з попереднім нанесенням шару клею за допомогою трафаретної форми (2) [5].

Під час проведення процесу тиснення на тканинах $€$ свої особливості та проблеми [6]. Основною є структура тканини, а також їі фізичні властивості, а точніше, стійкість їі волокон до нагрівання.

На основі попередньо розробленої класифікації [5] для проведення експериментальних досліджень було обрано десять типів тканин. Два зразки з натуральних волокон: бязь, джинс (100\% бавовна); сім зразків зі штучних волокон: атлас різного складу (два зразки), замша, костюмна тканина, трикотаж, хутровелюр, сатин; один зразок у складі якого містяться натуральні та штучні волокна. Їх характеристика наведена у табл. 1. Для

(๔) $2017 \mathrm{p}$. 
формування відбитка було відібрано два види фольги: Luxor AB та Luxor NX-N, характеристики яких наведено в табл. 2, а також клей на водній основі TEXIFLOCK ST.

Для реалізації експерименту використано ручний трафаретний верстат, трафаретну форму 3 лініатурою 34 нитки/см, термопрес DY-MF001 та позолотний прес.

Згідно з результатами попередньо проведених аналітичних досліджень $[7,8]$ було визначено, що основними параметрами варіювання будуть час та температура, тиск - незмінний. Спи- раючись на рекомендації виробників клею та фольги [6] та враховуючи термічні характеристики тканин, було прийнято рішення про те, що температура за технологією 1 варіюватиметься в межах $115-130^{\circ} \mathrm{C}$, час 25-40 c; за технологією 2: температура $150-175^{\circ} \mathrm{C}$, час $15-30 \mathrm{c}$.

Аналіз отриманих результатів за технологією 1 показав, що фольга Luxor AB не забезпечує бажану якість зображення фольга відлущується і ламається, a Luxor TX-N не призначена для цієї технології, оскільки відсутній адгезійний шар. Згідно з результатами попередніх дослі-

Таблиця 1

Характеристики тканин для проведення досліджень

\begin{tabular}{|c|c|c|c|}
\hline № зразка & Назва тканини & Склад & Товщина, мм \\
\hline \multicolumn{4}{|c|}{ Тканини з натуральних волокон } \\
\hline Зразок 1 & Бязь & Бавовна 100 \% & 0,19 \\
\hline Зразок 2 & Джинс & Бавовна $100 \%$ & 0,82 \\
\hline \multicolumn{4}{|c|}{ Тканини зі штучних волокон } \\
\hline Зразок 3 & Атлас & Поліестер 100 \% & 0,14 \\
\hline Зразок 4 & Атлас & $\begin{array}{c}\text { Віскоза } 30 \text { \% } \\
\text { Поліестер } 65 \% \\
\text { Еластан } 5 \text { \% }\end{array}$ & 0,23 \\
\hline Зразок 5 & Замша & $\begin{array}{c}\text { Поліестер } 95 \text { \% } \\
\text { Еластан } 5 \text { \% }\end{array}$ & 0,72 \\
\hline Зразок 6 & Костюмна тканина & $\begin{array}{l}\text { Віскоза } 98 \% \\
\text { Еластан } 2 \%\end{array}$ & 0,45 \\
\hline Зразок 7 & Трикотаж & Віскоза $100 \%$ & 0,25 \\
\hline Зразок 8 & Хутро-велюр & Поліефір 100 \% & 2,1 \\
\hline Зразок 9 & Сатин & Віскоза $100 \%$ & 0,25 \\
\hline \multicolumn{4}{|c|}{ Тканини з натуральних та штучних волокон } \\
\hline Зразок 10 & Сорочечна тканина & $\begin{array}{c}\text { Бавовна } 35 \% \\
\text { Поліестер } 65 \%\end{array}$ & 0,19 \\
\hline
\end{tabular}


Таблиця 2

Характеристики фольги для проведення досліджень

\begin{tabular}{|l|l|l|}
\hline \multicolumn{1}{|c|}{ Характеристика } & \multicolumn{1}{|c|}{ Фольга Luхоr TX-N } & \multicolumn{1}{c|}{ Фольга Luхоr AB } \\
\hline Сфера застосування & $\begin{array}{l}\text { Для нанесення декора- } \\
\text { тивних оздоблень на } \\
\text { текстиль }\end{array}$ & $\begin{array}{l}\text { Для нанесення на палі- } \\
\text { турні матеріали }\end{array}$ \\
\hline Основні властивості & $\begin{array}{l}\text { Для відтворення тонких } \\
\text { ліній та плашок. Стійка } \\
\text { до дії води }\end{array}$ & $\begin{array}{l}\text { Для відтворення серед- } \\
\text { ніх та крупних плашок }\end{array}$ \\
\hline $\begin{array}{l}\text { Температура та час } \\
\text { перенесення }\end{array}$ & 15-20 с при 180 C & 100-105 C \\
\hline Колір & Золото & Золото \\
\hline Кількість шарів & 4 & 5 \\
\hline
\end{tabular}

джень було прийнято рішення відмовитися від такої технології 1 під час проведення основних експериментів.

Важливим етапом у технології $2 €$ підготовка клею для формування зображення. Перед нанесенням на трафаретну форму клей необхідно перемішати до стану однорідної маси, за необхідності додати води. Технологічні особливості процесу нанесення клею на тканину представлені в табл. 3.

Результати попередніх досліджень технології 2 з використанням фольги для покривних матеріалів Luxor AB показали недо-

Таблиця 3

Технологічні особливості процесу нанесення клею на тканину

\begin{tabular}{|l|l|}
\hline Задруковуваний матеріал & Бавовна 100 \%, змішані тканини \\
\hline Сітка & максимум 34 н/см \\
\hline Емульсія & Zero-In UNIVERSAL PLUS Zero-In VERSA \\
\hline Ракель & $\begin{array}{l}\text { Форма та жорсткість профілю підбираються } \\
\text { залежно від бажаного кінцевого результату } \\
\text { відбитка }\end{array}$ \\
\hline Сушка & $\begin{array}{l}\text { За температури максимум 150 C, не більше } 2 \\
\text { хв. }\end{array}$ \\
\hline Термоперенесення & $\begin{array}{l}\text { Фольга: 150 C - 15 секунд } \\
\text { Відрив після повного охолодження }\end{array}$ \\
\hline Розріджувач & $\begin{array}{l}\text { За необхідності, вода в кількості максимум } 2 \\
\text { \% }\end{array}$ \\
\hline Уповільнювач & ТЕХILAC RITARDANTE GEL максимум 3 \% \\
\hline Очистка & Водою одразу після використання \\
\hline
\end{tabular}


цільність подальших досліджень у цьому напрямку, оскільки фольга має свій адгезійний шар і переноситься не лише на сформоване зображення, а й на всю поверхню зразка. Окрім того, фольга ламається й кришиться.

Для визначення меж варіювання температури та часу для термопресу було побудовано контурні графіки для кожного зразка, частина з яких представлено на рис. 1.

Специфіка зображення, утвореного покриттям фольгою тисненням, полягає в тому, що воно утворює або плашку, або штрихове зображення залежно від фактури тканини. Оцінка якості покриття всієї площі зображення представляє значну складність. Оцінка покривної здатності відбитків проводилась за

наступною методикою. 3 метою зменшення трудомісткості й підвищення точності оцінки виділялась макроділянка-свідок у вигляді прямокутника на місці зображення, що має найбільшу ймовірність дефектності. Виділена макроділянка розбивалась на мікроділянки, що мають розмір пікселя.

Повноту покривистості було визначено з використанням програмного забезпечення Adobe Photoshop CS6 та попередньо отриманих цифрових фотографій відбитків за допомогою цифрового мікроскопа. Після чого за допомогою піктограми CropTool вирізалася макроділянка з кількістю мікроділянок рівній або більше n; за допомогою команди Color Range виділялась область, покрита фольгою. Коефіцієнт
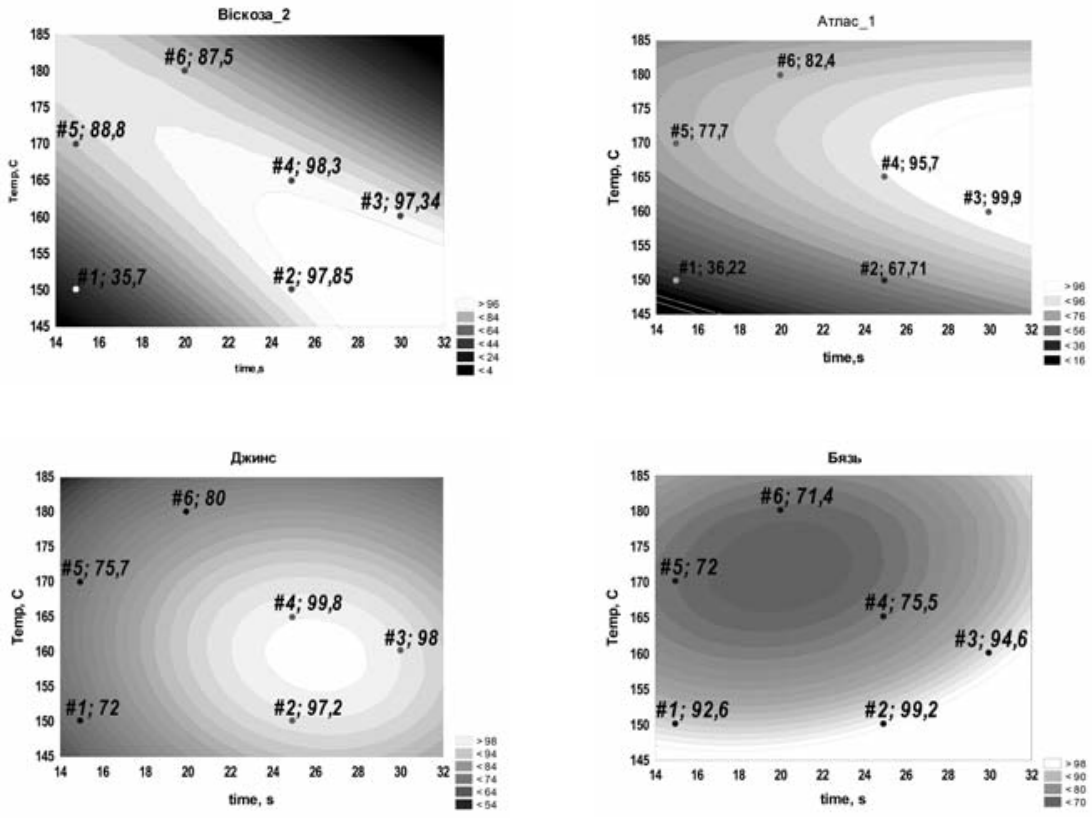

Рис. 1. Контурні графіки залежності відсотку перенесення фольги від температури та часу 
тональності (Fuzziness) обирався зважаючи на повне виділення основного тону макроділянки; у меню Image за допомогою команди Histogram знаходилося значення кількості пікселів, яке має виділене зображення на фотографії відбитка; розраховувалась повнота покривитості відбитка фольгою як відношення кількісті пікселів на фотографії відбитка до фольги на місцях зображення, помножене на 100, до загальної кількості пікселів виділеної ділянки:

$$
Q=\frac{K}{L} 100 \%
$$

де $Q$ - відсоток перенесеної фольги; L - const, кількість пікселів до нанесення фольги; K кількість пікселів нанесеної фольги.

Окрім об'єктивної оцінки покривної здатності відбитків за методикою, представленою вище, також було використано експертне візуальне оцінювання за шкалою від 1 до 5 (5 - найкра- ще перенесення, 1 - найгірше), результати якого представлено в табл. 4.

На основі отриманих даних було побудовано графіки залежностей відсотку перенесення фольги від часу за сталої температури (рис. 2).

\section{Висновки}

Визначено роль клейового шару у формуванні зображень. Лініатура трафаретної сітки під час перенесення клею становить 34 нитки/см. Товщина полімеризованого шару клею для тканин з рельєфною поверхнею становить 0,1-0,2 мм. Для нанесення клею на тканини з високим ворсом рекомендується використання вирізних трафаретів.

Визначено, що технологічні параметри процесу перенесення фольги на тканину залежать від походження волокон тканин. Для тканин з натуральних волокон рекомендовано вищі температури та час, зокрема для бавовняних тканин температура $165^{\circ} \mathrm{C}$ та час 30 с. Для тканин 3 синтетичних волокон температура
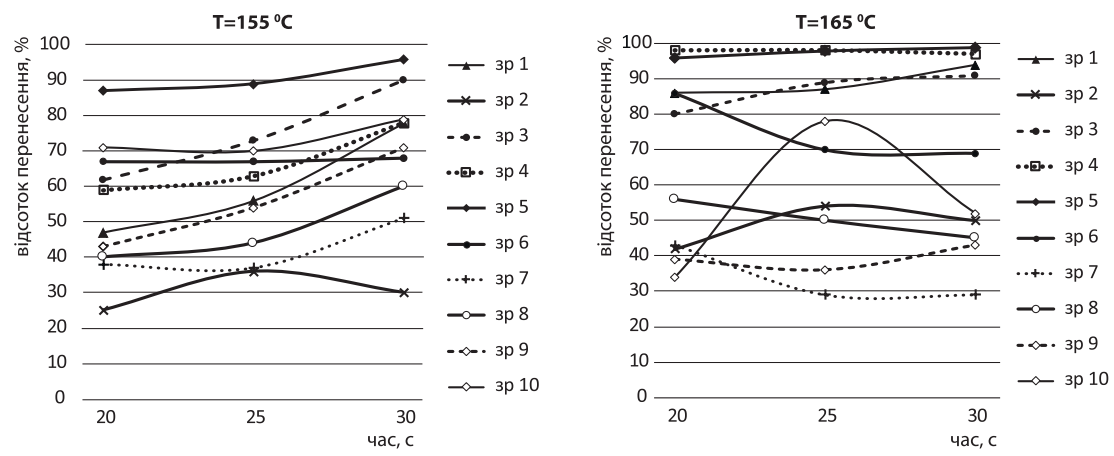

Рис. 2. Порівняльні графіки залежностей впливу часу на покривну здатність відбитка за температур $155^{\circ} \mathrm{C}$ та $165^{\circ} \mathrm{C}$ для десяти зразків 
ТЕХНОЛОГІЧ Н І П РО ЦЕ С И

Таблиця 4

Результати оцінки покривної здатності відбитка

\begin{tabular}{|c|c|c|c|c|c|c|c|c|c|c|c|}
\hline \multirow{2}{*}{$\begin{array}{c}\text { № } \\
\text { зра- } \\
\text { зка }\end{array}$} & \multirow{2}{*}{$\begin{array}{c}\text { Темпера- } \\
\text { тура, }{ }^{\circ} \mathrm{C}\end{array}$} & \multicolumn{3}{|c|}{155} & \multicolumn{3}{|c|}{160} & \multicolumn{3}{|c|}{165} & \multirow{2}{*}{$\begin{array}{l}\text { Кра- } \\
\text { щий } \\
\text { пока- } \\
\text { зник }\end{array}$} \\
\hline & & 20 & 25 & 30 & 20 & 25 & 30 & 20 & 25 & 30 & \\
\hline \multirow{2}{*}{1} & Оцінка \% & 47,2 & 56 & 78,1 & 85,8 & 92,3 & 92 & 86 & 87 & 94 & 94 \\
\hline & $\begin{array}{l}\text { Експертна } \\
\text { оцінка }\end{array}$ & 3,02 & 3,42 & 3,53 & 3,56 & 3,73 & 3,65 & 4 & 3,9 & 4,5 & 4,5 \\
\hline \multirow{2}{*}{2} & Оцінка \% & 25 & 36 & 30 & 37 & 45 & 51 & 42 & 54 & 50 & 54 \\
\hline & $\begin{array}{l}\text { Експертна } \\
\text { оцінка }\end{array}$ & 2,1 & 2,4 & 2,42 & 2,87 & 3,11 & 3,3 & 3,31 & 3,42 & 3,9 & 3,9 \\
\hline \multirow{2}{*}{3} & Оцінка \% & 62 & 73 & 90 & 81 & 89 & 94 & 80 & 89 & 91 & 94 \\
\hline & $\begin{array}{l}\text { Експертна } \\
\text { оцінка }\end{array}$ & 1,9 & 4 & 4,1 & 3,9 & 4,2 & 4,4 & 3,81 & 4,78 & 4,6 & 4,78 \\
\hline \multirow{2}{*}{4} & Оцінка \% & 59 & 63 & 78 & 91 & 97 & 81 & 98 & 98 & 97 & 98 \\
\hline & $\begin{array}{l}\text { Експертна } \\
\text { оцінка }\end{array}$ & 3,1 & 3,4 & 3,7 & 4,1 & 4,23 & 4 & 4,3 & 4,9 & 5 & 4,9 \\
\hline \multirow{2}{*}{5} & Оцінка \% & 87 & 89 & 96 & 98 & 99 & 99 & 96 & 98 & 99 & 99 \\
\hline & $\begin{array}{l}\text { Експертна } \\
\text { оцінка }\end{array}$ & 4,1 & 4,3 & 4,53 & 5 & 4,98 & 4,9 & 4,83 & 4,67 & 4,98 & 5 \\
\hline \multirow{2}{*}{6} & Оцінка \% & 67 & 67 & 68 & 48 & 91 & 88 & 86 & 70 & 69 & 91 \\
\hline & $\begin{array}{l}\text { Експертна } \\
\text { оцінка }\end{array}$ & 2,01 & 2,12 & 3,44 & 3,56 & 4,81 & 4,13 & 4,2 & 4,5 & 4,78 & 4,81 \\
\hline \multirow{2}{*}{7} & Оцінка \% & 38 & 37 & 51 & 35 & 35 & 48 & 43 & 29 & 29 & 51 \\
\hline & $\begin{array}{l}\text { Експертна } \\
\text { оцінка }\end{array}$ & 1,3 & 1,75 & 2,2 & 1,8 & 1,4 & 1,2 & 2 & 1,2 & 1,4 & 2,2 \\
\hline \multirow{2}{*}{8} & Оцінка \% & 40 & 44 & 60 & 58 & 56 & 56 & 56 & 50 & 45 & 60 \\
\hline & $\begin{array}{l}\text { Експертна } \\
\text { оцінка }\end{array}$ & 2,1 & 2,4 & 3,2 & 3 & 3,1 & 2,9 & 3,16 & 2,02 & 2,87 & 3,2 \\
\hline \multirow{2}{*}{9} & Оцінка \% & 43 & 54 & 71 & 77 & 79 & 78 & 39 & 36 & 43 & 79 \\
\hline & $\begin{array}{l}\text { Експертна } \\
\text { оцінка }\end{array}$ & 2,5 & 2,3 & 3,21 & 3,27 & 4,45 & 3,98 & 3,65 & 3,29 & 3,4 & 4,45 \\
\hline \multirow{2}{*}{10} & Оцінка \% & 71 & 70 & 79 & 76 & 81 & 79 & 34 & 78 & 52 & 81 \\
\hline & $\begin{array}{l}\text { Експертна } \\
\text { оцінка }\end{array}$ & 2,23 & 2,45 & 3,01 & 3,47 & 4,46 & 4,15 & 2,01 & 3,51 & 3,28 & 4,46 \\
\hline
\end{tabular}


та час процесу перенесення фольги нижчі, ніж для натуральних тканин, оптимальними $€$ температура $160^{\circ} \mathrm{C}$ та час $25 \mathrm{c}$. Відсоток перенесення фольги на синтетичні тканини є найвищим. Для тканин 3 високим вмістом віскози рекомендовано наступні параметри процесу: температура $155^{\circ} \mathrm{C}$, час $30 \mathrm{c}$.

\section{Список використаної літератури}

1. Берман Е. А. Технологии декорирования и дизайн трикотажных изделий для мелкосерийного производства: дисс. на соискание уч. степ. канд. техн. наук: 17.00.06 / Е. А. Берман. Иркутск, 2010. 199 с.

2. Крюкова Н. А. Разработка способа создания и закрепления отделки с объемными эффектами в изделиях из трикотажных полотен: дисс. на соискание уч. степ. канд. техн. наук: 05.19.04 / Н. А. Крюкова. М., 2004. 227 с.

3. Патент № 2178032. Российская Федерация, MПK D06Q1/08. Способ тиснения текстильных изделий / Крюкова Н. А., Конопальцева Н. М., Малыхин В. И.; патентообладатель Московский государственный университет сервиса; заявл. 30.12.99; опубл. 10.01.02.

4. Тиснение на коже или ЗД давленка [сайт]. Режим доступу: http:// 3decor-pr.ru/?page_id=648 (дата звернення 24.11.2017). Назва з екрана.

5. О. І. Хмілярчук. Аналітичний огляд технологій перенесення зображення на тканину / О. І. Хмілярчук, А. Д. Шепельова // Технологія і техніка друкарства. 2017. № 1(55). С. 38-46. DOI: https://doi.org/10.20535/20777264.1(55).2017.90086.

6. О. І. Хмілярчук. Технології перенесення металізованої фольги на текстильні вироби / О. І. Хмілярчук, А. Д. Шепельова // Технологія і техніка друкарства. Київ: НТУУ «КПІ» ВПІ, 2017. № 2(56). С. 45-53. Режим доступу: http://ttdruk.vpi.kpi.ua/article/view/90089.

7. Маїк В. Технології тиснення і фольгування / В. Маїк // Палітра друку. 2004. № 6.

8. Долгова Т. А. Исследование влияния технологических параметров на качество горячего тиснения фольгой / Т. А. Долгова // Труды БГтУ. Издательское дело и полиграфия. 2011. № 9. С. 41-45.

\section{References}

1. Berman, E. A. (2010). Tekhnologii dekorirovaniya i dizayn trikotazhnykh izdeliy dlya melkoseriynogo proizvodstva. Irkutsk, 199 p. [in Russian].

2. Kryukova, N. A. (2004). Razrabotka sposoba sozdaniya i zakrepleniya otdelki s ob'emnymi effektami v izdeliyakh iz trikotazhnykh poloten. Moscow, 227 p. [in Russian].

3. Kryukova, N. A. \& Konopal'tseva, N. M. \& Malykhin, V. I. Sposob tisneniya tekstil'nykh izdeliy // Patent RU № 2178032. Publish 10.01.02 [in Russian].

4. Tisnenie na kozhe ili 3D davlenka (2017). Retrieved from http://3decorpr.ru/?page id=648 [in Russian].

5. Khmiliarchuk, O. I. \& Shepelova, A. D. (2017). Analitychnyi ohliad tekhnolohii perenesennia zobrazhennia na tkanynu. Journal of Tekhnolohiia $i$ tekhnika drukarstva, 1(55), 38-46. DOI: https://doi.org/10.20535/20777264.1(55).2017.90086 [in Ukrainian]. 
6. Khmiliarchuk, O. I. \& Shepelova, A. D. (2017). Tekhnolohii perenesennia metalizovanoi folhy na tekstylni vyroby. Journal of Tekhnolohiia $i$ tekhnika drukarstva, 2(56), 45-53. Retrieved from http://ttdruk.vpi.kpi.ua/article/view/ 90089 [in Ukrainian].

7. Maik, V. (2004). Tekhnolohii tysnennia i folhuvannia. Journal of Palitra druku, 6 [in Ukrainian].

8. Dolgova, T. A. (2011). Issledovanie vliyaniya tekhnologicheskikh parametrov na kachestvo goryachego tisneniya fol'goy. Journal of Trudy BGTU. Izdatel'skoe delo i poligrafiya, 9, 41-45 [in Russian].

В статье представлены результаты исследований, направленных на оценку качества тиснения фольгой на тканях, а именно кроющей способности оттисков.

Также предложены рекомендации относительно оптимальных режимов технологического процесса по тиснению на разных по свойствам тканях.

Ключевые слова: кроющая способность оттисков; металлизированная фольга; перенос фольги на ткань; параметры процесса тиснения; горячее тиснение фольгой.

The article presents the results of studies aimed at evaluating the quality of foil stamping on fabrics, namely the covering capacity of prints. The recommendations of optimal modes of technological process of the embossing on tissues with different properties was proposed as well.

Keywords: covering capacity of prints; metallized foil; foil application on textiles; parameters of embossing process; hot foil stamping.

\author{
Рецензент - Ю. Ю. Віцюк, к.Т.н., доцент, \\ КП ім. Ігоря Сікорського
}

